\title{
Employability Skills Required amongst Unemployed Youth: A Case at Beverly Hills in the Sedibeng District, Southern Gauteng
}

\author{
Josiah Masoka \\ Faculty of Management Sciences, Vaal University Technology, \\ Vanderbijpark, South Africa \\ josiah@vut.ac.za \\ Jacob Selesho \\ Faculty of Management Sciences, Vaal University Technology, \\ Vanderbijlpark, South Africa \\ jacobs@vut.ac.za
}

Doi:10.5901/mjss.2014.v5n3p132

\begin{abstract}
The numbers of highly qualified, skilled and unemployed youth are increasing even though companies claim to be looking for skilled employees. The researcher is of the opinion that by assessing youth skills with the purpose of empowerment, the youth would broaden their options, revealing to them domains that they might not have thought of. It is in this regard that the paper intend to discover the skills required for employment purpose among school going youth. Quantitative and qualitative research approach was applied in this study, while the population for the study was four key target groups. The four key target groups of the target population consisted of the grade 11 and grade 12, unemployed graduates and matriculates at Beverly Hills in the Sedibeng district. A total number of 180 young persons were selected from a possible 7391 young people, to form part of the study. In analyzing the data, the researcher collected questionnaires and structured interviews for triangulation purposes. The study established that $60 \%$ of the unemployed youth are in possession of Grade 12 certificates, while $29 \%$ are either furthering studies at Universities or Further Education and Training Colleges. Only $11 \%$ have no formal education in the form of completing their grade 12 certificates. The argument that the increase in the rate of unemployment is as a result of lack of basic education is not a valid argument.
\end{abstract}

Keyword: Employability. Youth. Skills. Entrepreneurial.

\section{Introduction}

South Africa's growth trajectory in the last 20 years since attaining democracy has not absorbed labour at the required scale, and the lack of access to the labour market and wage income has driven up poverty and inequality, despite a significant rollout of social grants and basic services.

Although, the education system previously provided on the basis of demographics has since changed to the better and access to education has been increased with regard to equity profiles. This resulted in an increase in the number of youth who complete their higher education as well as formal schooling (Ransom, Poswa \& Van Rooyen 1999 \& Maunders 2003). While many more young people have access to education than the generation before them, they have been unable to access the economy at the required scale. Alarmingly, over $60 \%$ of South Africans under the age of 25 are unemployed or have been discouraged in their search for work

The numbers of highly qualified, skilled and unemployed youth are increasing even though companies claim to be looking for skilled employees. In a survey involving 273 employers, it was predicted that in the period of five years professional jobs would grow between 16-18 per cent, while those requiring little skill were expected to decrease by about 35 per cent (Census 2011).

South Africa has one of the highest unemployment rates (29.8 per cent) in the world, amounting to approximately 4.5 million unemployed people, of whom the majority are young people (Census 2011). According to Adries (2003) unemployment rates amongst youth are escalating, with young people between 16-25 years constituting 35.16 per cent, while those who are 26-35, make up 37.10 per cent of the unemployed and are still living in homes where their parents or guardians have never worked (Census 2011). 
With such a high number of jobless matriculated and graduated youths, the researcher is of the opinion that in South Africa illiteracy is not the only cause of unemployment and poverty (Rosenberg, Heimler \& Morote 2011). According to Robert (2002), youths are being given too much theoretical information during their studies and very few programs are implemented, that are aimed at developing these practical skills, enabling students to apply their knowledge in the practical world. Considering Robert's view South African Government showed commitment by promulgation of the skill development act 37 of 2008, this act gave birth to the Sector Education and Training Authorities with its purpose among others being to provide experience to unemployed youth through learnerships and other form of training. The establishment of this entity for the first time anticipates a coherent response to the education, training and skills development challenges faced by the country (Akoojee 2012). While the establishment of SETA's and other government entities that intend to improve the opportunities of youth employability, through skills programme, learnership and entrepreneurial skills are noticeable there is still much to be done.

Thus, assessing youth skills with the purpose of empowering them will assist service providers and the local municipality with information relevant to the needs of the youth in maximizing the individual's employability. The researcher is of the opinion that by assessing youth skills with the purpose of empowerment, the youth would broaden their options, revealing to them domains that they might not have thought of otherwise. It is in this regard that this paper intent to discover the skills required for employment purposes among school going youth.

\section{Review of Related Literature of Employability Skills to Both the Employers and Employees}

According to Overtoon (2000) and Davids (2002), the dual challenges of competing in a world of market and rapid technological advancements, have necessitated a redesign of the workplace into an innovative work environment. This environment requires behaviour and orientation towards work, and would expect workers at all levels to solve problems, create ways to improve the methods in use and engage effectively with their co-workers, customers and the community at large.

Employability skills are more important, because jobs today require individuals to undertake many different tasks. According to Kruss (2007) today's jobs are not as narrowly prescribed and defined as in the past and generally they are more service-oriented, touching on information and social skills. While, employers today use employability skills as a tool to select potential and competent candidates from the large number of applications they receive (Lankard 1990). Conversely, the positions which employers are offering today require workers to have a broader range of competencies than ever before, competencies that are job-specific but which include the kinds of management and organizational skills previously required only of supervisors (Miller, Biggard \& Newton 2013, Andrews \& Higson 2008).

From an employer's perspective, transferable skills are considered equally important as technical skills which have a pivotal role in allowing people to apply their technical abilities effectively in the workplace.

The new developments on employability skills have prompted a number of research projects by various research institutions abroad to investigate employers' grievances regarding graduates soft skills.

\subsection{Employability Skills in the South African Context}

Not much has been done in South Africa in terms of developing employability skills. According to Clark (1997), the current education and training system emphasis is on mathematics and science, intended to produce university entrance and graduates respectively. With reference to the literature review the researcher has undertaken, a number of youth skill development centres and donors to youth skills development have been put in place, of which almost all of them concentrate on giving practical skills, working experience and business skills.

South Africa's focus on skills is highly skewed, where Science, Engineering and Technology are of importance than other field. If one has to go through the census statistics (2011), it will mean that the problem facing unemployed graduates and matriculates could be lessened if the necessary steps are taken in the early development of employability skills.

The future economic growth of any nation or country is determined by the potential skills of its youth, not its capital or material resources. Youth, according to Dacey and Travers (1998), is a sensitive period in the growth of creativity and the youth are naturally creative and energetic if creative activities are offered to them at their childhood. Thus, according to Lemperes (2001), it is crucial to teach youth employability skills in order for them to survive and thrive in an information economy so as to combat unemployment and poverty amongst themselves. 


\section{Research Methodology}

A research design is a strategic framework for action that served as bridge between research questions execution and the implementation of the research problem. It can also be described as the plans that guide the process and the logistic that assisted in the collection and analysis of data (Terre Blanch, Durrheim \& Painter 2006). In conforming with the above-mentioned statement the study intends to collectively support the research objective, conceptualised as to identify the employability skills that need to be developed for young people from high school education level to higher education institutions, SETA's and other stakeholders. As already stipulated a quantitative and qualitative research approach was applied in this study, because it was considered to be a more relevant approach, because of the research design and the data collection instruments (Cohen, Manion \& Morrison 2007).

\subsection{Target population and sampling}

Population is described as the "full set of cases from which the research sample is taken" and to which the results obtained by testing a sample should be generalised (Welman, Kruger \& Mitchell 2009:53). The population for the current study was four key target groups which were prioritized for the participation in employability skills survey. The three key target groups of the target population consisted of the grade 12's, unemployed graduates and matriculates at the Beverly Hills in the Sedibeng district. Areas covered, included Beverly Hills and its extensions. The choice of this area was based on the fact that the rate of youth unemployment is estimated to be high in the Vaal Triangle region.

In this study a purposeful convenience sampling technique was applied in selecting the appropriate sample. According to Cohen et al. (2007:113), convenience sampling is described as a process where the "researcher select a particular group, in part or whole, at the convenience of the researcher". A total number of 180 young persons were selected from a possible 7391 young people, to form part of the study. From this 180 selected participants, 60 participants were grade eleven and grade twelve pupils from the two secondary schools available in that area. From a total number of $\mathbf{3 0 6}$ grade eleven learners of Beverly Hills, only 15 of them where selected to form part of the study. The selected sample was viewed to be appropriate for this study on the basis that the selected learners could be trained for skills empowerment.

\subsection{Data collection, analysis and interpretation}

In analyzing the data, the researcher collected questionnaires and structured interviews for triangulation purposes (McMillan \& Schumacher 2010). The structured questionnaires were administered to both sections, A and B here referred to as section $\mathbf{A}$ at the Beverly Hills area. The questionnaire contained open-ended questions and forced-choice questions. The collection of data from the subjects (participants) was aimed at gathering information regarding employability skills that need to be developed amongst the youth.

\section{Results and Discussions}

Creative thinking refer to the process of combining the components or ideas of phenomena, objects, events, systems or points of views in a unique manner which will better satisfy a need for individual or for the global market.

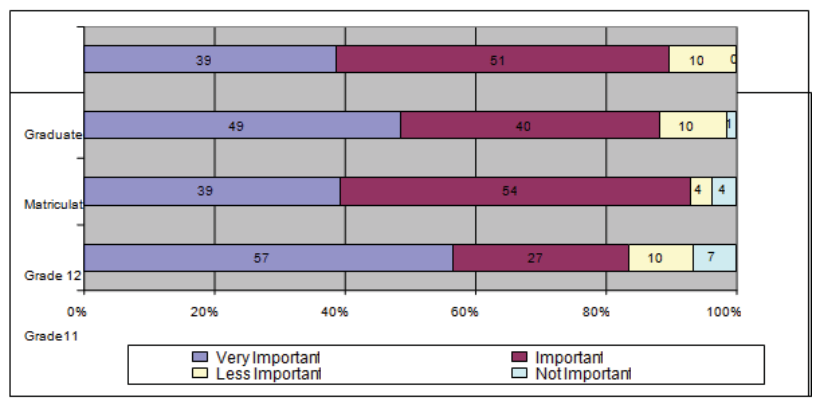


Figure 1: Creative thinking as a skill

Figure 1 explains how the different four categories of participants value creative thinking skills. The skill which they are lacking, important and also need to be developed is shown by value of important. 39\% of graduates valued creative thinking important which also indicated a need to be developed. 51\% value creative thinking skill "important" while $10 \%$ valued these skills "less important".

Matriculates responded as follows 49\% indicated "very important", 40\% responded with "important", 10\% indicated "less important", while only $1 \%$ t did not see any necessity of creative thinking skills.

Figure 1 relates to the creative thinking skill. 57\% of the grade eleven learners saw valued reliability as a "very important" skill, $27 \%$ indicated "important", while only 10\% indicated "less important", with $7 \%$ responding with "important". A total of $39 \%$ of grade twelve learners indicated "very important", $54 \%$ of indicated "important", while $4 \%$ gave a rating of "less important", and another $4 \%$ indicated "not important".

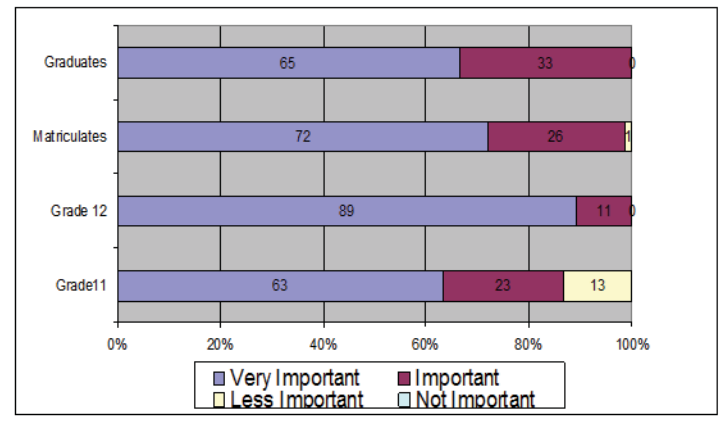

Figure 2: Self-discipline as a skill

Figure 2 relates to self-discipline as a skill. A total of $63 \%$ of the grade eleven learners responded with "very important", $23 \%$ indicated that it is "important", while $13 \%$ responded "less important". Of the grade twelve learners who gave the rating as "very important", comprises $89 \%$ while $11 \%$ indicated "important".

Matriculates responded at $72 \%$ saying it is "very important" $26 \%$ indicating "important", while only $1 \%$ responded by "less important". Graduates' shows a 65\% responded for "very important"; and 33\% indicated "important".

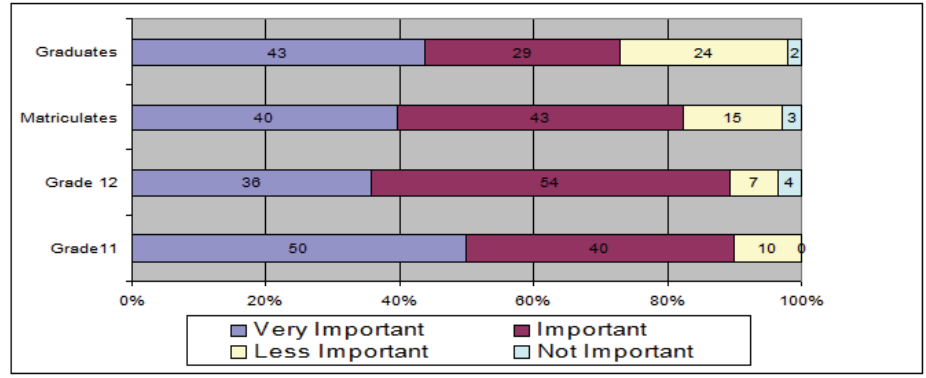

Figure 3: Independency as a skill

Figure 3 represent responses in respect of dependency as a skill. Independency refers to a person ability to work independently without close supervision. A total of $50 \%$ of the grade eleven learners valued independency as a skill as "very important", $40 \%$ indicated "important", while only 10\% said it is "less important". In respect of the grade twelve learners, $36 \%$ valued it as "very important", $54 \%$ indicated "important", $7 \%$ valued it "less important", while only $4 \%$ viewed it as being "not important".

Ratings for the matriculates indicated as follows: $36 \%$ indicated "very important", $54 \%$ valued it "important", $7 \%$ indicated "less important", while only $4 \%$ never saw any necessity of developing independency as a skill. From the graduates' point of view, 43\% valued independency as a skill "very important", $29 \%$ valued it "important" while $24 \%$ 
valued "less important", and only $2 \%$ indicated "not important"

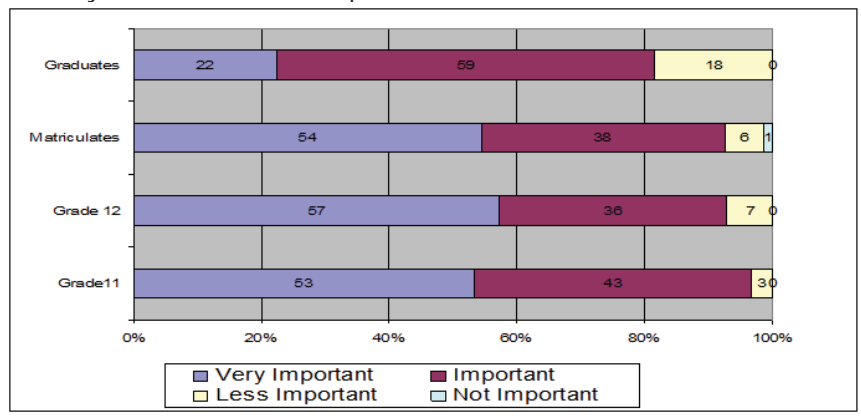

Figure 4: Interpersonal skills

Figure 4 provides feedback on the question of interpersonal skills. This question is about how well one relates with others and establishes a good working relationship. A total of $53 \%$ of the grade eleven learners responded with "very important", 43\%indicated "important", while only 3\% indicated "less important". Grade twelve learners: $57 \%$ indicated "very important", 36\% indicated "important", while 7\% gave the rating as being "less important".

A total of $54 \%$ of matriculates responded "very important", $38 \%$ indicated "important", $6 \%$ indicated "less important", while only1 percent never saw any necessity of developing interpersonal skills. From the graduates' perspective, 22\% are those who valued interpersonal skills "very important", 59\% indicated "important" while 18\% valued these skills "less important".

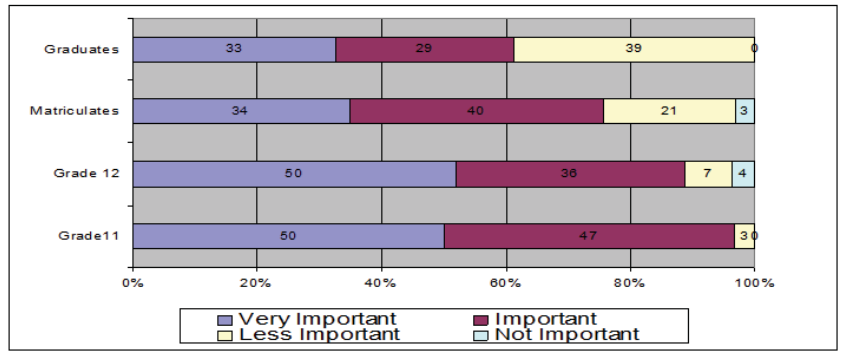

Figure 5: Problem-solving skills

Figure 5 gives feedback on problem-solving skills. A total of $50 \%$ of the grade eleven learners responded with "very important", 47\% responded with "important" while, only 3\% indicated "less important". Of the grade twelve learners, 50\% indicated "very important", $36 \%$ indicated "important", $7 \%$ gave the rating as "less important" while only $4 \%$ said "not important".

Matriculates' ratings showed the following: $34 \%$ said "very important", $40 \%$ indicated "important", $21 \%$ indicated "less important", while $3 \%$ did not consider problem-solving skills and the reason for these to be developed. From the graduates' perspective, 33\% valued at problem-solving skills as "very important," 29\% are those who valued it "important", while 39\% (majority) valued these skills "less important".

\section{Conclusion}

The study established that $60 \%$ of the unemployed youth are in possession of Grade 12 certificates, while $29 \%$ are either furthering studies at Universities or Further Education and Training Colleges. Only $11 \%$ have no formal education in the form of completing their grade 12 certificates. The argument that the increase in the rate of unemployment is as a result of lack of basic education is not a valid argument.

From the grade eleven and twelve's perspective, some of the skills classified as employability skills, are being introduced in life orientation subject. Life orientation covers skills such as,

* Interpersonal skills;

* Team-work; 
* Creative skills and

* Critical thinking.

However, the teaching of these skills does not get enough attention from that level because learners are often told by both teachers and government to focus more on Mathematics and Science at the expense of soft skills.

From the perspective of the graduates and matriculates, $97 \%$ of the unemployed matriculates and graduates revealed, that they had no idea as to what these employability skills are and do not even know what impact these employability skills has in their employability.

Although SETAs and other training centres like Make a connection are there much more work and still more need to be done to promote the teaching employability skills at all levels of education. Such provision by institutions of higher learning can minimise the increase in graduate unemployment as a result of the lack in employability skills.

\section{References}

Adries, B. 2003. Youth and work in South Africa, Department of Labour.

Akoojee S 2012. Skills for inclusive growth in South Africa. Promising tied amidst perilous waters. International Journal for Educational Development, 32(5):4-11.

Andrews J \& Higson H 2008. Graduate Employability, 'Soft Skills'Versus 'Hard' Business Knowledge: A European Study, Higher Education in Europe, 33:4, 411-422,DOI: 10.1080/03797720802522627

Barker, F.S. 2003. South African labour market, $4^{\text {th }}$ Ed. Pretoria: Van Schaik.

Bernstein, A. \& Schlemmer, L. 2000. Securing skills in international migration policy. Indicators South Africa 17(1): 51-58.

Bhorat H 2004. Labour market challenges in the post-apartheid South Africa. South African Journal of Economics, 72 (5):11-18.

Census 2011 Statistics. Sedibeng District Municipality. [Available on Internet] http://www.demarcation.org.za> [Date of access: 22 Jan 2014].

Clark, A. 1997. Survey on employability. [Available on Internet] http://thesuis.emeraldinsight.com>.

Clark, M.C. \& Payne, R.L. 1997. The nature and structure of workers' trust in Management, Journal of organizational Behaviour, 18(3): 3-9.

Cohen, L.; Manion, L. \& Morrison, K. 2007. Research Methods in Education. London:Routledge Falmer Publishers.

Cotton, K. 2001. Developing employability skills. School Improvement Research Series (SIRS).

Curtis, D. D \& Mckenzie, P. 2002. Employability skills for Australian industry: literature review and framework development: report to: Business Council of Australia, Australian Chamber of Commerce and Industry.

Dacey J.S \& Travers J.F. 1998. Skills For Today's Workforce 1998. Yukon Government chamber of commerce, Canada.

Davids, S. 2002. Labour market skills for a new economy. Making career sense of labour market information, chapter 4. [Available on Internet] http://www.making careersense.org>.

De Jager, H.C. 2004. Employer expectations and prospective employee realities: A model to address the need for Employable Skills.

Dench, S. 1997. "Changing skills needs: what makes people employable?" Industrial and Commercial Training, 29(6):7-11.

Denscombe, M. 2003. The good research guide, $2^{\text {nd }}$ Ed. Penn Plaza, New York.

Holdsworth, T. \& Gearhart, E. 2002. Teaching and assessing employability skills, modern machine shop, 74(12): $247-261$.

Kruss, G. 2007. Employment and employability: expectations of higher education responsiveness in South Africa. Journal of Education Policy, 19(6):17-24.

Lamperes, B. 2001. In business week on line. Innovating a better tomorrow. Academic search premier [Available on Internet] (http://search epnet. com>.

Lankard, B.A. 1990. The fifth basic skills. Eric Digest no 104, Eric clearing house on Adult Career and Vocational Education Columbus OH. New York.

Mcmillan, J.H. \& Schumacher, S. 2010. Research in Education. New York: Pearson Education, United States of America.

Miller L, Biggart A \& Newton B 2013. Basic and employability skills. International journal for educational development. 17(3):2267-2278.

Overtoon, C. 2000. Employability skills an update. Eric Digest no 220. Eric clearing house on adult career and vocational education, Columbus, $\mathrm{OH}$.

Pearsall, J. 2001. The Concise Oxford Dictionary. Oxford University Press. New York.

Ransom, B.L., Poswa, T. \& Van Rooyen, C.A.J. 1999. Youth unemployment: a study in an informal settlement in Kwazulu Natal. Social Work Stellenbosch 35(9):196-207.

Robert, P. 2002. Young Adults Develop Entrepreneurial Skills. Press anon.

Roger, B.H. \& Robert C.W. 2002. A factor analysis of primary mental processes for technological problem-solving. Journal of Industrial Teaching Education, 36(2):7-12.

Ross. L \& Bruce C. 2002. Harnessing technologies for sustainable development. Economic Commission for Africa.

Rosenberg S, Heimler R \& Morote E 2011. Basic employability skills: A triangular design approach.

Terre Blanche, M., Durrheim, K. \& Painter, D. 2006. Research in Practice: Applied methods for social sciences. Cape Town: University of Cape Town Press.

Welman, C., Kruger, Mitchell, B. 2009. Research Methodology. Cape Town. Oxford University Press. 